\title{
Yazınsal Metinlerde Yer Alan Karakter Geliştirme Yolları: Ortaokul Türkçe Ders Kitapları Örneği
}

\author{
DOI: 10.26466/opus.690174
}

$*$

\author{
Bașak Karakoç Öztürk * \\ * Doç. Dr., Çukurova Üniversitesi, Eğitim Fakültesi, Adana/Türkiye \\ E-Posta: bkarakoc@cu.edu.tr \\ ORCID: $\underline{0000-0002-5783-3471}$
}

\section{Öz}

Araştırmada ortaokul Türkçe ders kitaplarındaki yazınsal metinlerde kullanılan karakter geliştirme yollarının tespit edilmesi amaçlanmıştır. Bu amaç kapsamında doküman incelemesi yöntemi kullanılmış, ortaokul 5, 6, 7 ve 8. sınıflar için hazırlanan, Millî Ĕ̆itim Bakanlığ Talim ve Terbiye Kurulu Başkanlığ̊ tarafından eğitim aracı olarak kabul edilen Türkçe ders kitaplarındaki yazınsal metinler çalışma grubunu oluşturmuştur. Yazınsal metinlerin seçilmesinin nedeni, metin türü olarak kurmaca bir dünya yaratması ve bu kurmaca dünyanın farklı karakterlerin geliştirilmesine olanak sağlamasıdır. Bu bağlamda Türkçe ders kitaplarındaki 50 yazınsal metin kullanılan karakter geliştirme yolları açısindan incelenmiştir. Araştırmada veri toplama aracı olarak karakter geliştirme yolların içeren bir kontrol listesi kullanılmıştır. Söz konusu kontrol listesindeki karakter geliştirme yolları, Lukens tarafindan ifade edilen karakter geliştirme yollarıdır ve Türkçe ders kitaplarındaki yazınsal metinler bu kontrol listesi kullanılarak araştırmacı tarafından incelenmiş, merinler içerik analizi yöntemiyle analiz edilmiştir. Araştırma sonucunda tüm sınıf düzeylerine yönelik Türkçe ders kitaplarındaki yazınsal metinlerde en çok kullanılan karakter geliştirme yolunun karakterlerin konuşturulması olduğu, karakterlerin geliştirilmesinde en az fiziksel özelliklerin kullanıldığı saptanmıştır.

Anahtar Kelimeler: Karakter Geliştirme, Yazınsal Metin, Ortaokul, Türkçe Ders Kitabı. 


\title{
Character Development Methods in Literary Texts: A Case of Secondary School Turkish Textbooks
}

\begin{abstract}
The aim of the study was to determine the character development methods used in literary texts in secondary school Turkish textbooks. For this purpose, the document review method was used, and the study group consisted of literary texts in Turkish textbooks prepared for 5th, 6th, 7th, and 8th grades of the secondary school and accepted by the Turkish Ministry of National Education, Head Council of Education and Morality as the education tool. The reason for the selection of literary texts is that they create a fictional world as a type of text and this fictional world allows the development of different characters. In this context, 50 literary texts in Turkish textbooks were examined in terms of character development methods. In the study, a checklist containing character development methods was used as a data collection tool. The character development methods in the mentioned checklist are the character development methods expressed by Lukens, and the literary texts in Turkish textbooks were examined by the researcher using this checklist and the texts were analyzed by the content analysis method. As a result of the study, it was found that the most common character development method in literary texts in Turkish textbooks for all grade levels was to make characters speak, and the physical characteristics were least used in the development of characters.
\end{abstract}

Keywords: Character Development, Literary Text, Secondary School, Turkish Textbook. 


\section{Giriş}

Ders kitapları öğretmenler ve öğrenciler tarafından kolay ulaşılabilir ve kullanışlı olması nedeniyle kabul gören, eğitim öğretim sürecinin vazgeçilmez kaynaklarından biridir. Ders kitaplarının öncelikli olarak kullanılmasının nedeni ilgili dersin öğretim programıla uyumlu olması yani programa uygun olarak hazırlanmasıdır. Öğretim programlarında bulunan kazanımlara ulaşabilmek için gerekli olan etkinlikler ders kitaplarında yer almaktadır ve öğretim programlarındaki kazanımlar ders kitaplarının içeriğini belirlemektedir. Küçükahmet'e (2011) göre yetişmiş neslin, yetişmekte olan nesle kültürünü aktaran ve öğretim programıla öğrenci arasında köprü kuran en temel ve en önemli araç ders kitaplarıdır. Türkçe derslerinde de öğretim programının ulaşmayı amaçladığı kazanımların gerçekleşmesi için ders kitapları sıklıkla kullanılmaktadır.

Türkçe öğretiminin en önemli amacı dört temel dil becerisinin geliştirilmesidir. Bu süreçte ders kitaplarında yer alan metinlerin önemli bir işlevi bulunmaktadır. Çünkü dil becerilerinin Türkçe ders kitaplarında yer alan metinlerle bağlantılı olarak hazırlanan etkinliklerle geliştirilmesi amaçlanmaktadır. Ortaokulda yapılan okuma eğitiminde ilkokulda başlayan ilginin sürdürülmesi ve alışkanlı̆̆a dönüşmesi için çocukların nitelikli, ilgi ve zevklerine uygun, duygu ve düşünce dünyaların zenginleştirebilecek metinlerle buluşmaları çok önemlidir.

Aslan (2007, s.17) ilköğretim çağından başlayarak, çocuklarda dil sevgisi, dil bilinci ve duyarlılığının oluşmasına hizmet edecek; dilin tüm olanakları$\mathrm{nl}$, söz değerlerini yansıtan yazınsal metinlere anadili eğitim ortamlarında yeterince yer verilmeyiş̧inin dil becerilerinin geliştirilememesinin en önemli nedenlerinden biri olduğunu belirtmiştir. Sever (2006) ise Türkçe öğretiminde, öğrencilere dil bilinci ve duyarlığı kazandırmanın temel koşullarından birinin öğrencileri düzeylerine uygun, sanatçı duyarlığı ile hazırlanmış, nitelikli yazınsal ve öğretici metinlerle buluşturmak olduğunu vurgulamıştır.

Metin seçimi, okuma ilgisinin ve güdüsünün oluşması için bir önkoşul olarak görülebilir. Metin seçiminde yazınsallık belirleyici bir etmendir. Yazınsallık, yüzeysel anlatım yerine estetik nitelik ile ilgilidir. Bu tür metinler okurunu biraz zorlar, onların düşünsel bir etkinliğe ve üretime girmelerini zorunlu kılar (Dilidüzgün, 2004, s.51). Yazınsal metinlerdeki ileti kesin bir 
yargıya dönüştürülerek aktarılamaz. Metnin dokusuna sindirilir. Örtük ileti, gizli bir anlam, gizli bir öz yükler (Özdemir (1983, s.16). Dolayısıyla yazınsal metnin okurla iletişim kurma amacı bilgi vermek değildir.

Yazının iletisi sezgilere dönüktür. Bu ileti aklın ve duyguların birlikte hareket etmesiyle alımlanabilir. Yazın yaşatır, duyumsatır. Bu nedenle yazın yapıtı okuruna yaşantı zenginlikleri sunar, yaşam deneyimi kazandırır (Adalı, 2006, s.226). Yazınsal metnin yüzeydeki biçimsel özellikleri değil, ilettiği anlamlarla sunduğu dünyadır onu yazınsal yapan. Yazınsal metinlerin büyük çoğunluğu yaşadığımız dünyadaki durumlarla değerleri, bir kurmaca dünyanın kendine özgü tutarlılığı içinde, yeni ilişkilerde sunar. Bu bakımdan her yazınsal metnin kurmaca bir metin olduğu söylenebilir (Göktürk, 1997, s.45). Yazınsal metnin yazarı, yapıtıyla dış dünyadan farklı olarak oluşturduğu gerçekliğe okuru çağırmaktadır. Okur okuma sürecine girerek bu çağrıya kulak vermekte; sıradanlaşmış gerçeklik algısını sarsmaya başlamaktadır (Sartre, 2005, s.57). Bu bağlamda yazınsal metin karşısında okurun aktif bir rol üstlendiğini söylemek mümkündür. Çünkü yazınsal metinlerde yaratılan kurmaca dünya karşısında okur bilişsel özellikleri, ön bilgileri, deneyimleri, duyguları, hayal gücü, sosyal ve kültürel olanaklarıyla anlama, kurgudaki ipuçlarından yola çıkarak keşfetme ve anlamı yeniden yaratma süreci yaşamaktadır. Bu süreçte kurmacanın içinde var olan kişiler, olaylar etrafında gelişen ögeler olarak okurun yazınsal metinle kurduğu iletişimde çok önemli bir role sahip olacaktır.

\section{Yazınsal Metinlerde Karakter Kavramı ve Karakter Geliştirme Yolları}

Yazınsal metinlerde yer alan kişiler, okurun okuma sürecinde yakınlık kurmaya çalıştığı, bazen de öykündüğü, model aldığı ögedir. Okurun okuma eylemine başlamasında ve devam etmesinde metnin anlattıkları ve verdiği ileti kadar bunu kimlerle, ne tür özelliklere sahip kişilerle yaptığı da mühimdir. Bu durum okur kitlesinin çocuklar olduğu çocuk edebiyatı ürünleri açısından daha da önem arz etmektedir. Çünkü çocuk okurların okudukları kitaplardaki veya metinlerdeki kişilerle özdeşim kurması, okuma eyleminin niteliğini ve okumaya olan ilgisini arttırmaktadır.

Yazınsal yapitlardaki olay ve durumlarda yer alan ya da bunlara dolaylı bir biçimde karışan kimselere o yapıtın kişisi denmektedir. Kişiler, tipleştirme ya da karakterlendirme yoluyla yapıtlarda yer almaktadır (Özdemir, 
2002, s.131). Kişi, okurların büyük bir çoğunluğu için anlatının merkezdeki ögesidir. Öykünün tutarlılığını ve sürekliliğini sağlayan temel betidir, başka bir deyişle anlatının lokomotifidir (Kıran ve Kıran, 2000, s.133) Karakter ise roman, öykü, oyun gibi yazınsal bir üründe duygu, düşünüş, davranış ve tutkuları yönünden işlenen kişidir (Püsküllüoğlu, 1994, s.582), yazınsal yapıtların insanı insana tanıtma olan temel işlevine aracılık eden başat ögedir (Özdemir, 2002, s.222). Her yapıtta başından olay geçen kahramanlar, çeşitli karakterleri canlandırır. Karakter sanatçının yarattı̆̆ı; çeşitli yönlerden geliştirdiği; gerçek yaşamdan da esinlenerek deneyimiyle, birikimiyle, kendine özgü duyarlığı ile biçimlendirdiği bir kişiliktir (Sever, 2008, s.63-64).

Çocuk okurlar okudukları kitaplarda yer alan karakterle yakınlık kurduğu oranda kendi dünyasına bakabilmeyi ve içsel yolculuğa çıkabilmeyi başarmaktadır. Yaratılan karakterler çocuk okuru bazen öylesine etkilemektedir ki çocuk etkilendiği karakterin ardından diyara diyar dolaşabilmekte, onun yaşadıklarıyla, olaylara bakış açısıyla, kişiliğiyle ve verdiği tepkilerle ilişki kurabilmekte, kendini keşfetmekte, evrensel veya milli değerleri sezerek bazen karakterin özelliklerini kendi karakterinin bir parçası haline getirebilmektedirler. Karataş'a (2014, s.68) göre kurmaca dünyanın bir parçası hâline gelebilmenin anahtarı, karakterle "özdeşim" kurmaktır. Özdeşim özellikle çocukluk döneminde yakın çevreden birini ya da roman kahramanı, çizgi film/animasyon kahramanı gibi sanal kişileri rol model alma aşamasında önemlidir. İnsan metnin dünyasına ancak o dünyanın kahramanı ile özdeşim kurarak girebilmektedir.

Okuduğu ya da dinlediği bir öykünün kahramanıla ya da kahramanlarıyla kurduğu etkileşim, çocuğun yeni düşsel arkadaşlar edinmesini sağlar. Kendi gibi duyan, düşünen ve davranan başka çocukların da olduğunu ya da olabileceğini anlar. Kahramanlar aracılı̆̆ıyla, insanların başından geçebilecek olaylar hakkında bilgi edinir (Sever, 2008, s.76). Çocukların okudukları kitaplardaki veya Türkçe ders kitaplarında yer alan metinlerdeki kahramanlar, söz konusu kazanımları edinmeleri açısından oldukça önemlidir. Çocuk okurlar bu dönemde karşılaştıkları kahramanlar aracılığıyla kurmaca dünyaya dâhil olabilmekte veya bu dünyanın kapısını şöyle bir aralayıp geri kapatmaktadır. Dolayısıyla bu durum çocuğun okuma alışkanlığı kazanıp kazanmamasını etkileyen değişkenlerden biri olmakta, bu nedenle yazınsal metinlerdeki karakterlerin nitelikli bir şekilde geliştirilmesi önem kazanmaktadır. 
Karakter oluşturmak sanatçı duyarlılı̆̆ını, insanı bütün yönleriyle tanımayı bunun yanı sıra karakteri çizilecek kişinin eylemlerini, davranışlarını, çevresiyle ilişkilerini gözlemlemeyi gerektirir. Kişinin karakterini belirleyen bir bakıma bu ilişkilerdir (Özdemir, 2002, s.263). Lukens, Smith ve Coffel (2013: 114) karakter hakkındaki yargıları yeni tanışılan bir komşuyla ilgili edinilen izlenimlere benzetir. Komşumuzun evine gidildiğinde ilk olarak yaş, meslek ve sosyal durumları hakkında çeşitli yargılara varırız. Biraz daha gözlemlediğimizde konuşurken takındığı tavır ve giyim tarzına odaklanırız. Bu süreç sosyal anlamda ilgi çekerse yeni komşumuzun hayat görüşünü dinlemeye ve bu uğurda yaptıklarını düşünmeye isteklilik duyarız. Bütün bunlar bir araya getirildiğinde edebiyatta karakter terimini karşılayan kişilik ortaya çıkar (Akt. Karayel, 2018, s.14). Karakter geliştirme yollarını bilmek, bol bol okumak, çevredeki bireylerle okunanlar arasında özdeşim kurmak okurda karakteri anlama becerisini geliştirir (Binyazar ve Özdemir, 2006, s.119).

Lukens'e (1999) göre bir yazınsal metinde karakterler şu yollarla geliştirilmelidir:

- Davranışlariyla ve eylemleriyle,

- Karakterlerin konuşması yoluyla,

- Fiziksel özellikleriyle,

- Diğer karakterlerin yorumlarıla,

- Yazarin yorumuyla.

Kıran ve Kıran'a (2000) göre ise karakterlerin çözümlenmesi belirli ölçütlere göre gerçekleştirilebilir. Karakterler adlandırmalara göre, tanımlama ve bu tanımlamada kullanılan sözcüksel alanlara göre, ilk ortaya çıktığı zaman ve uzama göre, okurun karakteri tanımak için izlediği evrelere göre, yapıta ve diğer karakterlerle olan ilişkilerine göre çözümlenebilir. Karakterlerde bulunması gereken özellikler ve karakter sayıları okuru yapıta bağlamada önemli bir görev üstlenir. Bunların yanında bir diğer önemli konu da karakterlerin sunuluş yöntemleridir. Sadece yazarın anlatımı ya da sadece diyaloglarla karakterlerin tanitılması okuru tatmin etmeyebilir. Yazar karakteri tanitırken sunuş yöntemlerini ne kadar geniş tutarsa okuyucuyu yapita bağlama olasılığı o kadar yüksek olur (Çiçek ve Aksoy, 2016, s.117). Yazınsal metinlerde karakter geliştirmenin başarılı bir şekilde yapılması, çocuk okurların karakterleri farklı yönlerden tanımasını ve içselleştirmesini kolaylaştı- 
rabilir; okuma eylemine daha fazla ilgi ve istekle yönelmelerini sağlayabilir. Karakterler yoluyla okudukları metne bağlanan çocuk okurların okuma kültürü de daha etkili bir şekilde gelişim gösterebilir. Bu bağlamda ortaokul dönemindeki çocuklara okuma zevki ve alışkanlığını kazandırmak amacıyla temel araç olarak kullanılan Türkçe ders kitaplarının yazınsal metinlerdeki karakter geliştirme yolları açısından sorgulanması önem taşımaktadır. Bu önemden yola çıkarak yapılan araştırmanın amacı, ortaokul Türkçe ders kitaplarındaki yazınsal metinlerde kullanılan karakter geliştirme yollarının tespit edilmesidir. Bu amaç kapsamında aşağıdaki sorulara yanıt aranmıştır.

- 5. sınıf Türkçe ders kitabındaki yazınsal metinlerde kullanılan karakter geliştirme yolları nelerdir?

- 6. sınıf Türkçe ders kitabındaki yazınsal metinlerde kullanılan karakter geliştirme yolları nelerdir?

- 7. sınıf Türkçe ders kitabındaki yazınsal metinlerde kullanılan karakter geliştirme yolları nelerdir?

- 8. sınıf Türkçe ders kitabındaki yazınsal metinlerde kullanılan karakter geliştirme yolları nelerdir?

\section{Yöntem}

\section{Araştırmanın Modeli}

Araştırmada doküman incelemesi yöntemi kullanılmış; 5, 6, 7 ve 8. sınıf Türkçe ders kitaplarındaki yazınsal nitelikli metinler incelenen dokümanları oluşturmuştur. Dokümanlar, nitel araştırmalarda etkili şekilde kullanılması gereken bilgi kaynaklarıdır. Doküman incelemesi ise araştıılması hedeflenen olgu ve olgular hakkında bilgi içeren yazılı materyallerin analizini kapsamaktadır (Yıldırım ve Şimşek, 2005, s.187-188).

\section{Çalışma Grubu}

Araştırma kapsamında 2018-2019 eğitim-öğretim yılında; ortaokul 5, 6, 7 ve 8. sınıflar için hazırlanan, Millı̂ Eğitim Bakanlığı, Talim ve Terbiye Kurulu Başkanlığı tarafından eğitim aracı olarak kabul edilen Türkçe ders kitaplarındaki yazınsal metinler çalışma grubunu oluşturmaktadır. Yazınsal metinlerin seçilmesinin nedeni, metin türü olarak kurmaca bir dünya yaratması ve bu kurmaca dünyanın farklı karakterlerin geliştirilmesine olanak sağla- 
masıdır. Sever'in (2008) belirttiği gibi yazınsal metinler, okurda duygusal çağrışımlar uyandırmakta; okuru yeni bir anlayışa yöneltmekte,; sözcüklerle kurulan yeni anlam örüntüleri, okuru duymaya ve düşünmeye çağırmakta; örtük uyaranlarıyla da çok anlamlı bir özellik göstermektedir. Bu bağlamda 5. sınıf Türkçe ders kitabındaki 13 yazınsal metin, 6. sınıf Türkçe ders kitabındaki 10 yazınsal metin, 7. sınıf Türkçe ders kitabındaki 16 yazınsal metin ve 8. sınıf Türkçe ders kitabındaki 11 yazınsal metin, kullanılan karakter geliştirme yolları açısından incelenmiştir.

\section{Verilerin Toplanması ve Analiz Edilmesi}

Araştırmada veri toplama aracı olarak karakter geliştirme yollarını içeren bir kontrol listesi kullanılmıştır. Söz konusu kontrol listesindeki karakter geliştirme yolları Lukens tarafından ifade edilen karakter geliştirme yollarıdır ve kontrol listesi karakterlerin davranışlarıyla ve eylemleriyle, kendi konuşmalarıla, diğer karakterlerin yorumlarıla, fiziksel özellikleriyle ve yazarın yorumuyla geliştirilebileceğinden yola çıkarak hazırlanmıştır. Türkçe ders kitaplarından incelemek üzere seçilen toplam 50 yazınsal metnin her biri bu karakter geliştirme yollarının kullanılıp kullanılmadığı açısından kontrol listesi kullanılarak araştırmacı tarafından incelenmiş ve metinler içerik analizi yöntemiyle analiz edilmiştir. Yapılan analizler sonucunda elde edilen bulgulara yönelik güvenirliği arttırmak için yazınsal metinler Türk Dili ve Edebiyatı alanında uzman bir öğretim üyesi tarafından da analiz edilmiş, bulgular arasında uyuşum sağlanmıştır. Bununla birlikte bulgular açıklanırken metinlerde tespit edilen karakter yollarının örnekleri, metinlerden doğrudan alıntılar yapılarak sunulmuştur.

\section{Bulgular}

Bu bölümde ortaokul Türkçe ders kitaplarındaki yazınsal metinlerin analiz edilmesi sonucunda elde edilen bulgular metin adları ve her metinde kullanılan karakter geliştirme yolları tablolaştırılarak sunulmuştur. Tablo 1'de 5. sınıf Türkçe ders kitabındaki yazınsal metinlere yönelik bulgular yer almaktadir. 
Tablo 1. Beşinci sınıf Türkçe ders kitabındaki yazınsal metinlerde kullanılan karakter geliştirme yollar.

\begin{tabular}{|c|c|c|c|c|c|}
\hline $\begin{array}{l}\text { Karakter } \\
\text { Geliştirme } \\
\text { Metin Adı } \\
\end{array}$ & $\begin{array}{l}\text { Davranış } \\
\text { ve Eylemleriyle }\end{array}$ & Konuşmalarıyla & $\begin{array}{l}\text { Fiziksel } \\
\text { Özellikleriyle }\end{array}$ & $\begin{array}{l}\text { Diğer } \\
\text { Karakterlerin } \\
\text { Yorumuyla }\end{array}$ & $\begin{array}{l}\text { Yazarın } \\
\text { Yorumuyla }\end{array}$ \\
\hline Oyuncak & $\mathrm{X}$ & $X$ & & & \\
\hline Ben Bir Çınar Ağacıydım & & $x$ & & & \\
\hline Güneşin Uyuduğu Yer & $x$ & $x$ & & & \\
\hline Bilmeyen Var mı? & $x$ & $X$ & & & \\
\hline Küçük Ağa & $x$ & $x$ & $x$ & & $x$ \\
\hline Güvercin & $x$ & $x$ & & & \\
\hline Karagöz ile Hacivat- İncelik & & $x$ & & & \\
\hline Püf Noktası & $x$ & $x$ & & & \\
\hline Forsa & $x$ & $x$ & & & \\
\hline Çocuk Doğru Söyledi & $X$ & $x$ & & $X$ & \\
\hline Keramet Kavukta mı? & $x$ & $x$ & & $X$ & \\
\hline Hasta & $\mathrm{X}$ & $X$ & & $X$ & $X$ \\
\hline Kar Tanesinin Serüveni & & $x$ & & & \\
\hline TOPLAM & 10 & 13 & 1 & 3 & 2 \\
\hline
\end{tabular}

Beşinci sınıf Türkçe ders kitabındaki yazınsal metinlerde yer alan karakterlerin en çok davranışları, eylemleri ve konuşmalarıyla geliştirildiği Tablo 1'de görülmektedir. Bu bağlamda 5. sınıf Türkçe ders kitabındaki tüm yazınsal metinlerde karakterlerin kendi konuşmaları yoluyla geliştirilmesi önemli bir bulgu olarak göze çarpmaktadır. Karakterlerin davranışları ve eylemleriyle geliştirilmesine ise 10 yazınsal metinde yer verildiği görülmektedir. Bununla birlikte karakterlerin fiziksel özellikleriyle, diğer karakterlerin yorumuyla ve yazarın yorumuyla geliştirilmesine yazınsal metinlerde çok az yer verildiği tespit edilmiştir. Diğer karakterin yorumuyla karakter geliştirmeye 3 metinde, yazarın yorumuyla karakter geliştirmeye 2 metinde, fiziksel özellikleriyle karakter geliştirmeye sadece bir metinde yer verilmiştir. Analiz edilen metinlerden "Oyuncak" , "Karagöz ile Hacivat-İncelik" ve "Kar Tanesinin Serüveni" başlıklı metinlerden karakterlerin konuşmaları yoluyla geliştirilmesine yönelik şu örnekler verilebilir:

"Oyuncaklarla oynamak aslinda çocuklarm hakkı. Ama ne yapabilirim? Bu yaşta olmama rağmen ben de seviyorum oyuncaklarla oynamayı!"... Biliyorum, benim yaşımda birine aykır iş, böyle çocuklar gibi oynamak. Ama ne yapayım, elimde değil! Bir yanım çocuk kalmış! Çocukluğumsa çok, çok uzaklarda kaldı. Kaybettim gitti onu! Elektrikli trenlerim, yürüyen, konuşan taş bebeklerim filan olmadan!" (Oyuncak)

"Hacivat: Karagöz'üm insan önce bir selam verir, sende hiç incelik yok!.. 
Karagöz: Üzerimde gecelik var ya!..

Hacivat: Ne geceliği Karagöz'üm, incelik incelik...

Karagöz: O nasil şey?

Hacivat: Insanlar karşılaşınca birbirine selam verir.

Karagöz: Biz karşılaşmadık ki, sen beni uyandırdın." (Karagöz ile Hacivatİncelik)

"Evleri, ağaçları, yolları, tepeleri görmeye başlayınca sevindim. Şimdi de yeni bir merak sarmıştı beni. Neredeydim? Bu suya mı, ă̆aca mı yoksa bir binanın tepesine mi düşecektim? Bilemiyordum. Ama Hazar Denizi'ne düşmeyeceğim kesindi. Çünkü ortalıta deniz görünmüyordu." (Kar Tanesinin Serüveni)

Karakterlerin davranışları ve eylemleriyle geliştirilmesine yönelik örnekler ise "Güvercin" ile "Forsa" başlıklı metinlerden seçilmiş ve aşağıda sunulmuştur:

"Hazırlanmış tuzağı fark edemeyen güvercinler buğday tanelerini yemeye başlamışlar. Ne var ki bu ziyafetleri uzun sürmemiş. Hemen ağlara takılmışlar. Güvercinlerin yakalandığın gören avcı sevinçle onlara doğru koşmaya başlamış. Avcının kendilerine doğru sevinç çı̆̆lkları atarak koştuğunu gören güvercinler korkmuş. Bu korkuyla da kanat çırpmaya başlamışlar. Güvercinlerden bazıları da bağırı çă̆ırarak ağlamaya başlamış." (Güvercin)

"Karaya çıan bölükler, ellerinde al bayrak, kalenin etrafina doğru ilerliyorlardı. Kırk yıllık bir beklemenin verdiği son kuvvetle davrandı. Badem ağaçlarının çiçekli gölgeleriyle örtülen yoldan yürüdü. Kıyıya doğru koştu." (Forsa)

Karakterin diğer karakterlerin yorumuyla geliştirilmesine yönelik örneğe "Çocuk Doğru Söyledi" ve "Hasta" başlıklı metinlerde şu şekilde yer verilmiştir:

“Taht odası boşalınca Padişah, çoğu zaman yaptığı gibi Mimar'a yanında yer gösterdi.

- Dinle Mimarbaşı, dedi. Ülkemizi baştan başa sayısız camiler, mescitler, medreseler, kemerler, köprüler, saraylar, kervansaraylar, aşhaneler, hastaneler, hamamlarla donattın. Ama Padişah'ın için bir cami yapmayı düşündün mü hiç?" (Çocuk Doğru Söyledi)

"Yatak yumuşak, oda ılık, yaşayış tatl, herkes sevimli, yalnız ne kadar yazık ki çok sürmüyor! On gün sonra gelen giden seyrekleşti. Karısı da tavuk suyuna çorbayı pişirmez oldu: 'Sen pek gayretsiz oldun. İnan olsun ben senden daha hastayım. Yatsam, yatacağım. Bak bugün gene başım çatlyyor, ayakta zorla geziyorum.' demeye başladı."(Hasta) 
Beşinci sınıf Türkçe ders kitabındaki yazınsal metinlerde çok az rastlanan karakter geliştirme yollarından olduğu saptanan karakterin, yazarın yorumuyla geliştirilmesine yönelik örnekler "Küçük Ağa" ve "Hasta" başlıklı metinlerden aktarılmıştır:

"Birdenbire eğilerek Mehmet'i kaptı. Tam bir kapıştı bu. Mehmet korkmaya bile firsat vermeyen bir şaşkınlık içindeydi. Küçük A ğa boğazı düğümlenmiş, gözleri yana yana onu öptü, öptü, belki yüzlerce defa öptü; içine sindirmek isteyen bir hirsla

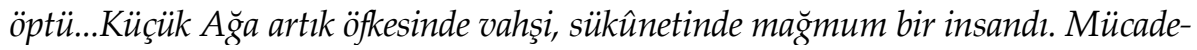
lede yırtıcl, dostluklarda ve kanaatlerinde fedai idi." (Küçük Ağa)

"Maliye Veznesi'nden Tevfik Efendi, banka önünde vezne arabasindan inerken nasıl oldu ise ayak bileğini incitmiş, iki gündür hasta, evde yatıyor. Komşular hatır sormaya geliyorlar. İki gündür evde yaşayış değişmiş, herkesten sıcak bir sevgi görüyor. Karısı, sanki o eski karısı değil, tanıdıkları eski tanıdıkları değil. Hepsi değişmişler, hepsinde, yalan da olsa tath bir sokulganlık, bir yaltaklık var." (Hasta)

Karakterin fiziksel özellikleriyle geliştirilmesine beşinci sınıf Türkçe ders kitabındaki "Küçük Ağa" metninde rastlanmış, söz konusu örnek aşağıda sunulmuştur:

"Mehmet korkunç şekilde annesine benziyordu. Ama yine de bu kapkara gözler, bu gür kaşlar, ağızdaki bu hüzün sinmiş irade Küçük Ağa'dandl, kendisindendi." (Küçük Ağa)

Altıncı sınıf Türkçe ders kitabındaki yazınsal metinlerde kullanılan karakter geliştirme yollarına yönelik bulgulara Tablo 2' de yer verilmiştir.

Tablo 2. Altıncı sınıf Türkçe ders kitabındaki yazınsal metinlerde kullanılan karakter geliştirme yollarn.

\begin{tabular}{|c|c|c|c|c|c|}
\hline Karakter & Davranış ve & Konuşmalarıyla & Fiziksel & Diğer & Yazarın \\
\hline Metin Adı & & & & $\begin{array}{l}\text { Karakterlerin } \\
\text { Yorumuyla }\end{array}$ & \\
\hline Canım Kitaplığım & $x$ & $x$ & & $x$ & \\
\hline Türk Askerinin Cesareti & $X$ & $\mathrm{X}$ & & & \\
\hline Yaşlı Nine & $X$ & $X$ & & & $x$ \\
\hline Aziz Sancar & $X$ & $\mathrm{X}$ & & & \\
\hline Vermek Çoğalmaktır & $X$ & $\mathrm{X}$ & & $x$ & $x$ \\
\hline Gümüş Kanat & $x$ & $X$ & $X$ & & $x$ \\
\hline Sır Tutamayan At Bakıcısı & $X$ & $x$ & & $X$ & $X$ \\
\hline Evinizi de Hatırlayın & & $x$ & & & $X$ \\
\hline Evet Efendim & & $X$ & & & \\
\hline Sen de Bir İyilik Yap & $X$ & $x$ & $X$ & $x$ & \\
\hline TOPLAM & 8 & 10 & 2 & 4 & 5 \\
\hline
\end{tabular}


Tablo 2'de görüldüğü gibi altıncı sınıf Türkçe ders kitabındaki yazınsal metinlerde karakterlerin en çok konuşmaları, davranışları ve eylemleri yoluyla geliştirildiği saptanmıştır. Altıncı sınıftaki tüm yazınsal metinlerde karakterlerin konuşmalarıyla geliştirilmesi sağlanmış, 10 metinden 8'inde karakterlerin davranışları ve eylemlerine yer verilmiştir. Bu karakter geliştirme yollarını karakterin yazarın yorumuyla ve diğer karakterin yorumuyla geliştirilmesi izlemektedir. Beş yazınsal metinde yazarın yorumuyla karakter geliştirilmesine yer verilmiş, diğer karakterlerin yorumuyla karakter geliştirmeye dört metinde rastlanmıştır. Ancak altıncı sınıf Türkçe ders kitabında karakterlerin fiziksel özellikleriyle geliştirilmesine ise oldukça az yer verildiği saptanmış, yalnızca iki metinde karakterler fiziksel özellikleriyle geliştirilmiştir.

Karakterlerin konuşmaları yoluyla geliştirilmesine yönelik alıntılar "Canım Kitaplığım”, “Türk Askerinin Cesareti”, "Sır Tutamayan At Bakıcısı” ve "Evinizi De Hatırlayın" başlıklı metinlerden sunulmuştur:

"Önce öğretmenimin önerdiklerini aldım. Okudum da. Bende okuma merakı geliştĭgini gören annem, babam, ă̆abeyim ve akrabalardan kimileri firsat buldukça bana kitap armağan ettiler. Bunlara, birkaç yaş günümde arkadaşlarmmin verdiklerini de eklersek varın siz hesap edin ne kadar çoğalmış. Hepsini okuyamadım. Birden yığıldılar. Ama büyük bir hızla okumayı sürdürüyorum. Yakında bitireceğim. (Canım Kitaplığım)

“Biz Avustralyallar, sizleri Gelibolu'da tanıdık ve sevdik. Ben de Çanakkale Savaşları'na teğmen rütbesiyle katılmış idim. Her iki tarafin da mertçe sürdürdü̆̈̈̈ savaşta edindiğim intibalar, hâlâ aym sıcaklıkla yüreğimde taşıyorum." (Türk Askerinin Cesareti)

“- Aman efendim! Ben size sadık kaldım. Sizin iyiliğinizi düşündüğü̈m için olan biteni hemen size söyledim. Sizin tarafınızı seçtim. Yaptıklarımın karşılı̆̆ bu muydu?" (Sır Tutamayan At Bakıcısı)

"Vallahi komşular bu öğ̈̈dümü iyi öğrenin. Bundan sonra hasta ziyaretine gittiğinizde evinizi de hatırlayın, başka bir diyeceğim yok, haydin güle güle, der." (Evinizi De Hatırlayın)

İncelenen "Türk Askerinin Cesareti”, “Gümüş Kanat" ve "Sen de İyilik Yap" başlıklı metinlerde karakterin davranışları ve eylemleri yoluyla geliştirilmesine yönelik şu örnekler yer almaktadır: 
"Siperin içinden iri yapılı bir er çıtı. Ucuna mendil bağladığı silahını yere attı. İki kolunu açtı. Sonra kendine güvenen tavırlarıla yavaş yavaş yaralı Yüzbaşı'ya doğru yürümeye başladı." (Türk Askerinin Cesareti)

"Su içmek için musluğa koştu. Kuşu sol avucuna aldr. Su içti. Sonra parmaklarmmn ucunu islattı. Bir eli ile kuşu o büyük avucunda tutuyor, bir eli ile de incecik ayaktan iplikleri çözüyordu" (Gümüş Kanat)

"Üzerine rastgele bir şeyler geçirdi. Yürüyerek gideceği için spor ayakkabısını giydi ayağına. Evden çıkmadan unuttuğu bir şey var mı diye düşündü bir an. Sonra kapıyı çekti. Anahtarı çevirdi. Sokağa çıktı̆̆ında yürümekten cayarak taksiyle gitmeye karar verdi." (Sen de İyilik Yap)

Karakterlerin yazarın yorumuyla geliştirilmesine yönelik örnekler "Vermek Çoğalmaktır" ve "Gümüş Kanat" metinlerinden aktarılmıştır:

"Talebenin yüzü kızardı. Böyle güzel bir hediyeyi hak ettiğini düşünmüyordu. Bu üzümlerin güzelliğini ve harikah̆ğın kimse kitaplardan sorumlu talebeden fazla takdir edemezdi" (Vermek Çoğalmaktır)

"Gümüş renkli kanatlarını çırpıyordu. Kendini dala çekmek istiyordu. Fakat kuvveti tükenmiş olacak ki çırpınmaktan vazgeçti." (Gümüş Kanat)

Altıncı sınıf Türkçe ders kitabındaki yazınsal metinlerde karakterin fiziksel özellikleriyle geliştirilmesinin çok az rastlanan bir karakter geliştirme yolu olduğu görülmüştür. Bu örnekler "Gümüş Kanat" ve "Sen de İyilik Yap" başlıklı metinlerde şu şekilde yer almaktadır.

"Babası dalgah sarı saçlarn ile tipkı aslana benziyordu. Gür ve kumral kaşl, uzun boylu, geniş omuzlu, kuvvetli ve gençti. Böyle önüne bakarken kendisini görenlere çok ciddi bir insan hissini verirdi. Fakat başın kaldirnca bir çift tatl ve mavi göz ılık, yumuşak bir ışıkla insanın yüreğine uzanırdı." (Gümüş Kanat)

"Siska denecek kadar zayıf bir çocuktu Canol. Üstündeki ceket korkuluğa giydirilmiş sanırdınz. Ama Güliz Hanım onu pek güzel bir delikanlı olarak gördü." (Sen de İyilik Yap)

Yedinci sınıf Türkçe ders kitabındaki yazınsal metinlerde yer alan karakter geliştirme yolları Tablo 3'te sunulmuştur. 
Tablo 3. Yedinci sınf Türkçe ders kitabındaki yazınsal metinlerde kullanılan karakter geliştirme yolları.

\begin{tabular}{|c|c|c|c|c|c|}
\hline $\begin{array}{l}\text { Karakter } \\
\text { Geliştirme Yolları }\end{array}$ & $\begin{array}{l}\text { Davranış ve } \\
\text { Eylemleriyle }\end{array}$ & Konuşmalarıyla & $\begin{array}{l}\text { Fiziksel } \\
\text { Özellikleriyle }\end{array}$ & $\begin{array}{l}\text { Diğer Karakterlerin } \\
\text { Yorumuyla }\end{array}$ & $\begin{array}{l}\text { Yazarın } \\
\text { Yorumuyla }\end{array}$ \\
\hline \multicolumn{6}{|l|}{ Metin adı } \\
\hline Arıların İlhamı & & $X$ & & & $X$ \\
\hline Munise & $X$ & $x$ & $X$ & $X$ & \\
\hline Dostluk & & $x$ & & & \\
\hline Eşek ve Köpek & & $X$ & & & $X$ \\
\hline Ordular! İlk Hedefiniz & $X$ & $X$ & & & $x$ \\
\hline $\begin{array}{l}\text { Öğretmeninizden } \\
\text { Af Dileyeceksiniz }\end{array}$ & $\mathrm{X}$ & $X$ & & & $x$ \\
\hline $\begin{array}{l}\text { Bir Şehidin Son } \\
\text { Mektubu }\end{array}$ & & $x$ & & & \\
\hline Sol Ayağım & $X$ & $X$ & & $X$ & \\
\hline Üç Soru & $\mathrm{X}$ & $X$ & & $X$ & \\
\hline Ben, Mimar Sinan & & $X$ & & & \\
\hline Muhacir Osman & $X$ & $X$ & & $X$ & $X$ \\
\hline Piri Reis & & $X$ & & & $x$ \\
\hline $\begin{array}{l}\text { Evrene Açılan } \\
\text { Gizli Anahtar }\end{array}$ & & $X$ & & & $X$ \\
\hline $\begin{array}{l}\text { Dîvânu } \\
\text { Lugât'it-Türk'ün } \\
\text { Bulunuş Hikâyesi }\end{array}$ & & $X$ & & & $x$ \\
\hline İlk Kar & & & & & \\
\hline Yıldırım Sesli Manasçı & & $x$ & & & \\
\hline TOPLAM & 6 & 15 & 1 & 4 & 8 \\
\hline
\end{tabular}

Yedinci sınıf Türkçe ders kitabındaki yazınsal metinlerde karakterlerin en çok konuşmalarıyla geliştirildiği ve 15 yazınsal metinde bu yolla karakter geliştirmeye yer verildiği Tablo 3 'te görülmektedir. Bunu yazarın yorumu ile davranış ve eylemleri izlemektedir. Diğer karakterlerin yorumu ve fiziksel özellikleriyle karakter geliştirmeye ise çok az yer verildiği saptanmıştır. Yedinci sınıf Türkçe ders kitabında karakterlerin konuşmaları yoluyla geliştirilmesine yönelik olarak saptanan örneklerden bazıları şunlardır:

"İçimde sönük bir ümit yok değildi. Çok güzel bulduğumuz için hiçbir zaman elimize geçmeyecek sandiğımız şeylere karşı duyulan o ümitsiz ümit. Munise'de neticesiz bir rüya uyandırmaktan korkar gibi yavaş bir sesle Hatice Hanım'a dedim ki: - Mademki bu kızl, evlerine istemiyorlar. Acaba ben, onu kendime evlat etmek istesem razı olurlar mı? Benim de kimsem yok. Vallahi bu çocuğa kendi evladım gibi bakarm. Acaba vermezler mi?"(Munise)

“Ben, Mimar Sinan! 29 Mayıs 1490 yılında, Kayseri'nin Ağırnas köyünde doğdum. O gün, İstanbul'un fethinin 37. yıl dönümüudü. Sevgili gençler! 98 yıl yaşa- 
dım. Devlete, tam 70 yıl hizmet ettim. Size hayatımı ve çağımı anlatmak istiyorum. İlginç bulacağınızı umuyorum. Yavuz Sultan Selim döneminde, birkaç yıllık bir eğitimden sonra İstanbul'daki acemi ocă̆ına alındım... Benim için, küçük Ağırnas köyünden sonra, İstanbul'da her şey ilginçti. Bir imparatorluğun yüreğinde dolaşyordum. Ama bu koca kentte bir yapı, beni özellikle kendine çekmeye başladı. Bu Ayasofya'ydr." (Ben, Mimar Sinan)

"Ben kendi benzerlerimle yoluna devam eden bir kuşum sadece. Leyleklerle beraber uçarm, onlardan biriyim. Gündüzleri şehirlerin, tarlaları üzerinde, karanlı gecelerde ise ylldzlar arasında, hep onlarla uçarım. Ve düşüncelerim de benimle beraber yüzer." (Yıldırım Sesli Manasçı)

Karakterlerin yazarın yorumuyla geliştirilmesine "Muhacir Osman", "Evrene Açlan Gizli Anahtar" ve "Dîvânu Lugâti't-Türk'ün Bulunuş Hikâyesi" başlıklı metinlerden alıntı yapılarak aşağıdaki örnekler verilmiştir:

"Biz çocuklar Osman Aga derdik kendisine, büyükler ve akranlarn Uzunlarn Osman... Köyde adı en çok duyulanlardan biriydi. Güçlüydü, açık elliydi. Alabildiğine de şendi. Çayır biçmede, bă̆ bellemede, odun kesmede onun üstüne yoktu. Birinin çalışkanlığın mı övecekler; tıpkı Uzunların Osman, derlerdi. Ramazan'da, bayramda davul mu çalmacak; bunu Osman Aga'dan başka becerecek birini kimse düşünmezdi."(Muhacir Osman)

"Neredeyiz biz?" George o kadar şaşırmıştı ki korkusunu unutmuştu. Kendini inanılmaz derecede hafiflemiş hissediyordu. Çevresine bakındl; kayalar, buz, kar, karanlıktan başka bir şey göremedi. Birinin uzaya firlattı̆̆g kocaman kirli bir kartopunun üstünde durmak gibiydi bu. Yildizlar her tarafta parlyordu fakat kızgin parıltılar Dünya'dan görüldüğü hâliyle göz kırpıştıran ışıklardan epey farklıydı." (Evrene Açılan Gizli Anahtar)

"Kitap dostu Ali Emîrî'nin bilgisi, dikkati, kitap sevgisi ve çabalarn olmasaydı eser bilgisiz ellerce belki de yok edilecek, dilimizin ve kültürümüzün en büyük hazinesinden mahrum kalacaktık." (Dîvânu Lugâti't-Türk'ün Bulunuş Hikâyesi)

Yedinci sınıf Türkçe ders kitabında yer alan yazınsal metinlerden "Öğretmeninizden Af Dileyeceksiniz", "Sol Ayağım” ve "Üç Soru” başlıklı metinlerde karakterlerin davranışları ve eylemleri yoluyla geliştirilmesine yönelik aşağıdaki örnekler verilmiştir:

"Yeni hocayı gözleri hiç tutmadı. Kafa kafaya verdiler ve hemen karara vardılar: Yeni hocayı istemeyeceklerdi. Ertesi gün yeni hoca kızlara bir şeyler söyledi. İkisi birden karşı gelmiş, hocanın sözünü dinlememişlerdi. Birden hocanın hiddetle ba- 
ğırdığı duyuldu. İkisini de kapı dışarı etmişti." (Öğretmeninizden Af Dileyeceksiniz)

"Ayak parmaklarm arasında tebeşiri sıkıca tuttum ve bir dürtüyle hareket edip kara tahtanm üzerine sert bir karalama yaptım. Sonra durdum, biraz şaşkın ve hayretle ayak parmaklarım arasindaki sarı tebeşir parçasına daha sonra ne yapacağımı bilmeden, onun oraya nasıl geldiğini anlamaksızın bakakaldım." (Sol Ayağım)

"Kral arkasinı döndü ve ormandan koşarak gelen sakall bir adam gördü. Adam, ellerini karnına bastırmıştı. Parmaklarmın altından kanlar akıyordu. Krala ulaştığında, hafifçe inledi ve bayllarak yere düştü. Karninda büyük bir yara vardı. Kral yarayı elinden geldiğince temizledi ve üzerini mendili ve münzevinin havlularından biriyle iyice sardr." (Üç Soru)

Karakterlerin diğer karakterin yorumuyla geliştirilmesine yedinci sınıf Türkçe ders kitabında çok az yer verildiği saptanmış, elde edilen bulgulardan seçilen örnekler aşağıda sunulmuştur:

“Görmüyor musun?" diye yanıtladı münzevi. "Dün benim gücssüzlüğ̈̈me actmayı benim için bu çiçeklikleri kazmasaydin ve kendi yoluna gitseydin, o adam sana saldıracaktı ve sen de burada benimle kalmadı̆̆ın için pişman olacaktın. Yani en önemli zaman çiçeklikleri kazdiğın zamandr. En önemli adam bendim ve en önemli işin de bana iyilik yapmaktı. Sonrasında o adam bize koştuğunda eğer yaraların sarmasaydın, seninle barış sağlayamadan ölecekti. $O$ zaman da o adam en önemli insandı ve ona yaptı̆̆ı̆ şey en önemli işindi." (Ü̧̧̈ Soru)

"Babam: -Kısmet, diyordu. Kısmet öyleymiş. Osman ne yapabilirdi ki? Tutmuş çeteciler kendisini, eline para verip "Bize kasabadan bu eşyaları alacaksın." demişler. "Hayır." desen öleceksin. "Evet." desen ölme tehlikesi var. Birisi peşin ölüm... Osman gene akıllı davrandı, ölümden kaçtı." ."(Muhacir Osman)

Yedinci sınıf Türkçe ders kitabındaki yazınsal metinlerde karakterin fiziksel özellikleriyle geliştirilmesine sadece "Munise" başlıklı metinde şu şekilde yer verilmiş̧ir: "Son kuvvetini tükettiği anlaşlan Munise, kollarımda baygin gibiydi. Yüzü mosmor, saçları dağılmış, elbisesinin içine karlar dolmuştu....Kolları boynumda, sarı saçları bileklerimden dökülerek gözlerime bakıyor, sorduğum suallere ağır ă̆ır cevap veriyordu. " (Munise)

Sekizinci sınıf Türkçe ders kitabındaki yazınsal metinlerde saptanan karakter geliştirme yolları Tablo 4 'te sunulmuştur. 
Tablo 4. Sekizinci sını Türkçe ders kitabındaki yazınsal metinlerde saptanan karakter geliştirme yollar.

\begin{tabular}{|c|c|c|c|c|c|}
\hline $\begin{array}{l}\text { Karakter } \\
\text { Geliştirme Yolları } \\
\text { Metin adı }\end{array}$ & $\begin{array}{l}\text { Davranış ve } \\
\text { Eylemleriyle }\end{array}$ & Konuşmalarıyla & $\begin{array}{l}\text { Fiziksel } \\
\text { Özellikleriyle }\end{array}$ & $\begin{array}{l}\text { Diğer } \\
\text { Karakterlerin } \\
\text { Yorumuyla }\end{array}$ & $\begin{array}{l}\text { Yazarın } \\
\text { Yorumuyla }\end{array}$ \\
\hline Mart1 & $X$ & $X$ & & $X$ & $X$ \\
\hline Acele Karar Vermeyin & & $x$ & & $x$ & $X$ \\
\hline Vatan Yahut Silistre & & $X$ & & $X$ & \\
\hline Atatürk'e Mektup & $X$ & $x$ & & $x$ & \\
\hline Yirmi Beş Kuruş & $X$ & $X$ & & $X$ & $X$ \\
\hline Bir Baba / Bir Zihniyet & & $X$ & $X$ & & \\
\hline Burada Dur & $X$ & $X$ & & & \\
\hline Ergenekon Destanı & $X$ & $\mathrm{X}$ & & & $\mathrm{X}$ \\
\hline Değirmende Döner Taşım & & $X$ & $X$ & & $\mathrm{X}$ \\
\hline Emine Teyze'nin Çilek Reçeli & $X$ & $X$ & & & $\mathrm{X}$ \\
\hline Bilge Adamin Yolu & $X$ & $X$ & & & $\mathrm{X}$ \\
\hline Haritada Bir Nokta & $X$ & $x$ & $X$ & $X$ & $X$ \\
\hline TOPLAM & 8 & 12 & 3 & 6 & 8 \\
\hline
\end{tabular}

Tablo 4'te görüldügü̈ gibi sekizinci sınıf Türkçe ders kitabında yer alan yazınsal metinlerde en çok kullanılan karakter geliştirme yolu karakterlerin konuşmalarıyla geliştirilmesidir. Nitekim sekizinci sınıf Türkçe ders kitabındaki tüm yazınsal metinlerde karakterlerin konuşmaları yoluyla geliştirildiği saptanmıştır. Bunu karakterlerin yazarın yorumu ile geliştirilmesi ve karakterlerin davranış ve eylemleri ile geliştirilmesi izlemektedir. Karakterlerin diğer karakterin yorumuyla ve fiziksel özellikleriyle geliştirilmesine ise daha az yer verildiği görülmektedir. Sekizinci sınıf Türkçe ders kitabında karakterlerin konuşmaları yoluyla geliştirilmesine yönelik örnekler "Martı", "Yirmi Beş Kuruş" ve "Emine Teyze'nin Çilek Reçeli" başlıklı metinlerden sunulmuştur:

"Bir kemik bir tüy kalmak umurumda bile değil anne. Ben sadece havada ne yapıp ne yapamayacağımı öğrenmek istiyorum, anliyor musun, hepsi bu." (Martı)

"- Senin yaşında belki senden biraz daha küçük bir çocuktum. Arkadaşlarımla okulun bahçesinde top oynuyorduk. Heyecanımız son sinırdaydr. Nihayet maç bitti. Yenik takımdaki arkadaşlar, acele ile ceketlerini giyip oradan uzaklaştılar. Arkadaşlarımıdan sonra biz de ceketlerimizi giymek için sahanın kenarma geldik. Giyinirken bir de ne görelim: Yerde bir yirmi beş kuruş durmuyor mu? Hepimiz heyecanlandık çünkü o zaman için bu büyü̈k bir para sayıllıdı." (Yirmi Beş Kuruş) 
"Sen ne diyorsun Mehmet Bey oğlum, elli çeşit reçel yaparm ben. Patlican reçelinden tut, muz reçeline kadar. Elime ne geçerse onun reçelini yaparım." (Emine Teyze'nin Çilek Reçeli)

Karakterlerin yazarın yorumuyla geliştirilmesine "Acele Karar Vermeyin" ve "Bilge Adamın Yolu" başlıklı yazınsal metinlerden alıntılar yapılmış ve aşağidaki örnekler verilmiştir:

"Köyün birinde yaşl bir adam varmış. Çok fakirmiş ama Kral bile onu kıskanırmış. Öyle dillere destan bir beyaz atı varmış ki Kral bu at için ihtiyara neredeyse hazinesinin tamammı teklif etmiş ama adam satmaya yanaşmamış." (Acele Karar Vermeyin)

"Rüzgâr limanı köyünün sakinleri cam yapımında kelimenin tam anlamıyla ustaydılar. Köyün en parlak çocuğu Narkissos, farkllĭğı ve özgünlüğ̈̈yle dikkat çekiyordu. Kıyafetindeki küçük ayna ve mercekler ile kafasındaki caml süslemeler, hiç şüphesiz bilge adamın gözlerini kamaştıracak, seçilen çocuk da Narkissos olacaktı. Güneydeki pamuk tarlalarmm arasında Dokumacllar köyünün sakinleri, kendine özgü güzelliğiyle bilge adamı büyüleyeceğine inandıkları Manolya'yı seçmişlerdi. İ̆ne iplik işlerinde en yetenekli insanlar olduklarından Manolya için kat kat kumaşlar dokuyup en şık elbiseleri dikmişlerdi." (Bilge Adamın Yolu)

Sekizinci sınıf Türkçe ders kitabındaki "Martı", "Burada Dur" ve "Ergenekon Destanı" başlıklı yazınsal metinlerden karakterlerin davranışları ve eylemleri yoluyla geliştirilmesine yönelik saptanan bazı örnekler aşağıda sunulmuştur:

“İki yüz fitte gagasını dik bir şekilde aşağı eğip elli milin üstüne çıtığı her anda kanatlarm sabit tutarak dalmayı tekrar denedi. Bu, çok büyük bir gü̧̧ istiyordu fakat yavaş yavaş oluyordu. Onuncu saniyede doksan mil hiza ulaştı. Böylece Jonathan, martılar arasında dünya hız rekoru kırmış oluyordu fakat bu başarısı hiç de uzun ömürlü olmadı. Hızını yavaşlatmaya, kanat açısını değiştirmeye kalkıştığı an ayn felaketle karşılaştı, kontrolünü kaybetti. Saatte doksan mil hiz yaparken hava akımı ona bir dinamit gibi çarptı, Martı Jonathan sanki havada patladı ve tıpkı betona çarpar gibi denize çakıldı." (Martı)

"Dağ denilmez, aşıllvr; tepe denilmez, aşıllvr. Köyler geçilir, obalar geçilir. Her ŭ̆ranılan, her geçilen yer Selçuklunun topraklarına katılır. Ne kadar, kaç gün gidilmiş, bilinmez. Bir akşama doğru bir vadide ilerlerken Sultan'ın kulağına bir ses gelir: "Burada dur!.." Sultan, rüyasındaki uyarıyı hatırlar. Atını durdurup orada konaklamaya karar verir. Çadırlar kurulur, bir oba oluşur." (Burada Dur) 
"Hep birlikte gidip demir madenini gördüler. Demircinin sözlerini de beğendiler. Dağın geniş yerine bir kat odun, bir kat kömür dizdiler. Daha sonra dağın üstünü, arka yanın, öte yanın, beri yanın bir sıra odun, bir sıra kömürle doldurduktan sonra yetmiş deriden yetmiş körük yapıp yetmiş yerde kurdular. Odunlarla kömürleri ateşleyip körüklediler." (Ergenekon Destanı)

Karakterin diğer bir karakterin yorumuyla geliştirilmesine "Martı" ve "Vatan Yahut Silistre" metinlerinden aşağıdaki örnekler verilmiştir:

"Neden Jon, söylesene neden?" diye inleyerek sordu annesi. "Diğerleri gibi olmak bu kadar zor mu? Alçaktan uçmak pelikanlar ve albatroslarm işi, bunu onlara bırakmalısın. Hem niçin avlanmıyorsun oğlum? Artık bir kemik bir tüy kaldın." (Marti)

"Sttkı Bey: Gel oğlum! Gel Bey'im! Gel arslanım! Dünyada, ahirette yüzün ak olsun. Vataninı sevenlere ne büyük ibret dersi gösterdin. Vatan aşk ete kemiğe bürünse elbet sen olurdun. Kahramanliklarmı Abdullah'tan işittim. İşitmeye de gerek yoktu ya! Seni bir kere gören, senin iki sözünü işiten ne olduğunu anlar." (Vatan Yahut Silistre)

Karakterin fiziksel özellikleriyle geliştirilmesine yönelik olarak "Bir Baba/Bir Zihniyet", "Değirmende Döner Taşım" ve "Haritada Bir Nokta" başlıklı yazınsal metinlerden alınan örnekler aşağıda sunulmuştur:

"Gayet kibar giyinmiş, saçları ağarmış, elli altmış yaşlarında bir zat kapımı çald.." (Bir Baba/Bir Zihniyet)

"Haydar Amca saçın değirmende gerçekten ağartmış, işini severek yapan, kırmızı suratl, elleri ve iri parmakları nasır bağlamış, boğuk sesli, başında papak eksik olmayan bir adam." (Değirmende Döner Taşım)

"Sekizincisini - zayıf, sarı, hastalkklı adamı - hiç görmemiştim." (Haritada Bir Nokta)

\section{Tartışma}

Ortaokul Türkçe ders kitaplarındaki yazınsal metinlerde kullanılan karakter geliştirme yollarının tespit edilmesi amacıyla gerçekleştirilen araştırmada tüm sınıf düzeylerinde en çok kullanılan karakter geliştirme yolunun karakterlerin konuşturulması olduğu saptanmıştır. Karakterlerin metin içerisinde konuşması, olaylar ve durumlar karşısındaki duygu ve düşüncelerinin, iç dünyalarının, tepkilerinin çocuk okur tarafından saptanmasında çok etkilidir. Çünkü çocuk okurun karakteri birçok yönden tanıması, karakterle ku- 
racağı bağın niteliğini etkilemektedir. Bu açıdan karakterlerin diyaloglar yoluyla veya iç konuşmalarla metnin içinde var edilmesi önemlidir. Forster'a (1985, s.127) göre yazarın okuru etkilemek için en güçlü silahlarından biri karakteri konuşma yöntemiyle geliştirmektir. Robin Carr tarafından da diyalogların kurmacayı zenginleştirmek ve canlandırmak için mükemmel bir buluş olduğu belirtilmiş; hayatta olduğu gibi ağızlarını açana dek okurun karakterleri tanıyamayacağı, bu bağlamda öykünün özünün karakterler arasında geçen konuşmalardan oluştuğu vurgulanmıştır (Akt. Çakır, 2002). Ahmet Hamdi Tanpınar (1977, s.66) “Öyküden bahsedilirken konuşma pek az hatıra gelir. Hâlbuki bugünkü öykünün yükünü asıl o taşır. Öykü bitince bu kahramanlar gene susmazlar. Bu sefer sizin içinizde konuşurlar." diyerek kahramanın okur üzerindeki etkisini vurgulamıştır. Bu etkiden yola çıkarak ortaokul Türkçe ders kitaplarında karakter geliştirme yollarından konuşma yönteminin sıklıkla kullanılması olumlu bir nitelik olarak değerlendirilebilir.

Araştırma kapsamında karakterlerin konuşmaları yoluyla geliştirilmesinden sonra en çok davranışları ve eylemleri yoluyla geliş̧tirildiği saptanmıştır. Bulgularda görüldüğü gibi özellikle 5, 6 ve 8 . sinıf Türkçe ders kitaplarındaki çoğu yazınsal metinde karakterlerin davranış ve eylemlerine yer verilerek geliştirildikleri tespit edilmiştir. Doğan Güldenoğlu (2017) tarafından yapılan araştırmada da yerli ve yabancı çocuk romanlarındaki yetişkin ve çocuk karakterlerin geliştirilme yolları incelenmiş, araştırma sonucunda yetişkin ve çocuk karakterlerin en çok davranış ve eylemleriyle geliştirildiği saptanmıştır. Mardi'ye (2006: 62) göre çocuk kitaplarındaki karakterler, çocuklar için her zaman olumlu ya da olumsuz bir örnek teşkil eder ve bu durum göz önüne alındığında çocuğun olumlu anlamda örnek alacağı bir karaktere benzemeye çalışması davranışlarını şekillendirme noktasında çocuğa yardımcı olur. Karakterin yaptığı bir eylemin içerisinde tanıtılması çocuk okurun macera duygusunu tatmin etmesi, kurgunun hareketlenmesi ve karakterin kendi kaderini kendisinin yaşayabilmesi (Kıran ve Kıran, 2000) adına önemlidir. Gerçekçi ve sağlıklı bir biçimde karakter çizme, insanı bütün yönleriyle tanımayı gerektirir. Karakteri çizilecek kişinin eylemlerini, davranışlarını, çevresiyle ilişkilerini gözlemlemeyi gerektirir (Özdemir, 2002, s.263). Dolayısıyla yazınsal metinlerde karakterlerin davranışlarına ve eylemlerine yer verilmesi çocuk okurun karakteri daha ayrıntılı şekilde gözlemlemesine ve çok yönlü tanımasına katkıda bulunacaktır. Bu gözlemler ve 
tanıklıklar çocuk okurların karakterlerle yakınlık kurmasında veya onlarla olan farklılıklarını sezmesinde yardımcı olarak etkili bir özdeşim kurma süreci yaşanmasını sağlayacaktır.

Karakterlerin konuşmaları, davranışları ve eylemleri dışında yazarın karakterler hakkında yaptığı yorumlar da karakter geliştirme yollarından biridir. Yazar, bir karakter veya diğer karakterler hakkında yorumlar yaparak karakterin çeşitli yönleriyle tanıtılmasında ve ortaya çıkmasında rol oynar. Aksoy'a (2009, s.34) göre bazen yazar da hikâye içinde herhangi bir baş kişi kadar rol oynamaya karar verebilir. Kurmaca anlatı türünde bazen olay örgüsü ile karakter öğeleri daha önemli görünseler de bir filmi anlamakta kamera açılarının farkında olmak ne kadar gerekliyse, yazarın görüş açıs1nın farkında olmak da o kadar gereklidir. Ancak yapılan araştırma sonucunda ortaokul 5. ve 6. sınıf Türkçe ders kitaplarındaki yazınsal metinlerde karakterin yazarın yorumuyla geliştirilmesine oldukça az yer verildiği tespit edilmiştir. Bununla birlikte 7. ve 8. sinfflarda ise bu karakter geliştirme yolunun daha fazla kullanıldığı saptanmıştır. Yazınsal nitelikli metinlerde, karakterlerin yaratıcısı olan yazar tarafından yorumlanması ve bu yolla okura tanıtılması, çocuk okurların karakterlerin daha örtük yanlarını tanımasını ve metnin iletisinin onlara ulaşmasını kolaylaştırabilir. Ayrıca karakterlerin çeşitli psikolojik ve sosyal özelliklerinin yazar tarafından ortaya konması çocuk okurun insan ve toplum gerçekliğini kavramasındaki etkisini arttırabilir.

Yazınsal metinlerde kullanılabilecek karakter geliştirme yollarından biri de karakterin diğer karakterlerin yorumuyla geliştirilmesidir. Araştırma sonucunda elde edilen bulgulara göre tüm sinıf düzeylerindeki ortaokul Türkçe ders kitaplarında bu karakter geliştirme yolunun az kullanıldığı saptanmıştır. Oysaki karakterlerin çocuk okurlara sadece kendi konuşmaları veya yazarın tanıtımıyla değil farklı karakterlerin dillerinden ve bakış açısından aktarılmasına çalışılarak farklı sunuş yollarıyla sunulmasına ve böylece çocuk kitaplarının teknik açıdan da güçlendirilmesine önem verilmelidir (Karataş, 2014). Yazınsal metin içerisinde bir karakterin başka bir karakter tarafından tanitılmasıyla karakterler sadece kendilerini değil, diğer karakterleri de tanıtmış olurlar. Böylece çocuk, hem yorum yapan hem de yorum yapılan karakterlerle ilgili bilgi edinme, yine onları tanıma olanağı bulabilir. Böylece doğrudan çocuk ve karakter arasında, dolaylı olarak ise 
çocuk ve kitap arasında oluşabilecek olumlu iletişimin adımlarının atılması sağlanabilir. (Doğan Güldenoğlu, 2017, s.4775).

Araştırma sonucunda ortaokul Türkçe ders kitaplarındaki yazınsal metinlerde en az kullanıldığı saptanan karakter geliştirme yolunun karakterin fiziksel özellikleriyle geliştirilmesi olduğu görülmüştür. Karagöz (2014) tarafından yapılan araştırmada da "Bintepe'nin Hayaleti" adlı yapıtta yer alan karakterlerin çözümlemesi yapılmış, karakterlerin geliştirilme süreci örneklendirilmiş ve bu araştırma sonucunu destekleyecek nitelikte karakterlerin fiziksel özelliklerine daha az yer verildiği saptanmıştır. Bir karakteri fiziksel özellikleriyle geliştirmek, onun sahip olduğu özelliklerin okurun zihninde canlanmasına, gözle görünür bir nitelik kazanmışçasına var olmasına, bazı ruhsal özelliklerinin de tahmin edilebilmesine katkı sağlayacağ için önemlidir. Aktaş ve Gündüz'e (2010) göre başarılı yazarlar, yaptıkları betimlemelerde sadece görünüşü sözcüklerle vermez, beş duyuyu da öğrenme eylemine katarak tadın, rengin, kokunun uyandırdığı ruh hâlini vererek okurda coşku uyandırırlar. Dış görünüşleriyle geliştirilen karakterler çocuğun hayal dünyasında somutlaşır; bir başka ifadeyle karakterin fiziksel özellikleri onun sınırlarının belirginleşmesine katkı sağlar ve özdeşim daha kolay olur. Fiziksel özellikleriyle betimlenen ve bu özellikleriyle karakter arasında bir ilişki kurabilen yazar çocuğun dünyasına daha çok seslenebilecektir (Karayel, 2018, s.51). Buradan yola çıkarak Türkçe ders kitaplarındaki yazınsal metinlerde karakterlerin fiziksel özellikleriyle geliştirilmesine yeterince yer verilmemesinin olumsuz bir nitelik olduğu söylenebilir.

\section{Sonuç ve Öneriler}

Araştırma sonucunda ortaokul Türkçe ders kitaplarındaki yazınsal metinlerde en çok kullanılan karakter geliştirme yolunun karakterlerin konuşturulması olduğu saptanmıştır. Özellikle 5. ve 6. sinıflarda karakterlerin davranış ve eylemlerine yer verilirken, diğer karakter geliştirme yollarının yeterince kullanılmadığı tespit edilmiştir. Yedinci ve sekizinci sınıflarda ise karakterlerin fiziksel özellikleriyle ve diğer karakterlerin yorumuyla geliştirilmesine oldukça az yer verildiği saptanmıştır. Oysaki karakterlerin geliştirilmesi sürecinde metin içinde konuşturulmaları onların duygu ve düşüncelerinin, iç dünyalarının, tepkilerinin çocuk okurlar tarafından daha iyi anlaşılmasını sağladığı gibi örneğin fiziksel yönlerden de tanıtılması karakterle- 
rin okurun zihninde somutlaşmasına ve psikolojik, kültürel vb. farklı özellikleri hakkında çıkarımlarda bulunmasına katkı sağlamaktadır. Başka bir karakterin yorumuyla geliştirilmesi ise okura, karakterlerin olay örgüsündeki rolünün farklı bir bakış açısıyla sezdirilmesine yardımcı olabilmektedir. Bu nedenlerle karakter geliştirme sürecinde çeşitli yollara başvurmak karakterlerin çok yönlü bir şekilde geliştirilmesini ve çocuk okurların kurmacanın içine daha etkili şekilde girmesini sağlamaktadır. Bu bağlamda Karatay'ın (2011) da belirttiği gibi hikâyede sadece bir yolla betimlenen karakter derinlikten yoksunlaşmakta, sadece bir boyutuyla sunulmuş ve vurgulanmış olmaktadır. Bu durum ise çocuğun karakterle özdeşim kurmasını olumsuz yönde etkileyen, çocuk edebiyatında tercih edilmeyen bir sonucu doğurmaktadır. Yazınsal nitelikli metinlerde farklı karakter geliştirme yollarının kullanılması ilgili literatürde (Dilidüzgün, 2007; Sever, 2008, s.2013) de benimsenen bir yaklaşımdır. Buradan yola çıarak ve araştırma sonucunda elde edilen bulgulara dayanarak araştırma kapsamında şu önerilerde bulunulabilir:

Türkçe ders kitaplarında bulunan yazınsal metinlerde karakter geliştirmenin hangi yollarla gerçekleştirildiği üzerinde önemle durulması gereken bir konudur. Çocukların okudukları metinlerdeki karakterlerle özdeşim kurabilmesi ve bu yolla karakterleri içselleştirebilmesi için onları çeşitli yönleriyle tanıması gerekmektedir. Bu nedenle Türkçe ders kitaplarına seçilen yazınsal nitelikteki metinlerde karakterlerin sadece konuşmalarıyla veya davranışlarıyla değil diğer yollarla da geliştirilip geliştirilmediği incelenmelidir. Türkçe öğretmenleri kitap seçimi yaparken öğrencilerine çeşitli karakter geliştirme yollarının kullanıldığı kitaplanı tanıtmaya gayret etmeli, bu yolla onları okumaya teşvik etmelidir. Ayrıca Türkçe öğretmenleri öğrencilerini okunan metinlerde veya kitaplarda farklı yollarla geliştirilen karakterlerin metne ve okura katkısının ne olduğu üzerinde düşünmeye ve tartışmaya yönlendirmelidir. Sonuç olarak araştırma kapsamında, ortaokul Türkçe ders kitaplarındaki yazınsal metinlerde yer alan karakter geliştirme yolları tespit edilmiş, bununla birlikte bazı karakter geliştirme yollarının daha az kullanıldığı saptanmıştır ve karakterlerin farklı yollarla geliştirilmesinin ne denli önemli olduğu vurgulanmıştır. Bazı karakter geliştirme yollarına ortaokul Türkçe ders kitaplarında daha az yer verilmesinin nedeni öğrencilerin ilkokul düzeyinde özellikle karakterlerin fiziksel özellikleriyle tanıtılmasına yönelik etkinliklerle daha çok karşılaştıklarının veya ilgili ör- 
nek metinleri daha çok okuduklarının düşünülmesi olabilir. Bu bağlamda daha sonra yapılacak araştırmalarda ortaokul düzeyindeki çocukların okuması için önerilen bazı çocuk kitaplarındaki karakter geliştirme yollarının irdelenmesi ve farklı değişkenlerle ilişkilendirilmesi önerilebilir. 


\title{
EXTENDED ABSTRACT
}

\section{Character Development Methods in Literary Texts: A Case of Secondary School Turkish Textbooks}

\author{
Başak Karakoç Öztürk \\ Çukurova University
}

The heroes in the texts in the books that children read or in the Turkish textbooks are very important in terms of acquiring the aforesaid gains. Child readers can be included in the fictional world through the heroes they encounter in this period, or they open and close the door of this world. Therefore, this situation is one of the variables that affect whether the child gains a reading habit or not, therefore it is important to develop the characters in literary texts in a qualified manner.

According to Lukens (1999), characters in a literary text should be developed in the following ways:

- With their behavior and actions,

- Through the speech of the characters,

- With its physical properties,

- With the comments of other characters,

- By the author's comment.

According to Kuran and Kuran (2000), the analysis of characters can be carried out according to certain criteria. The characters can be analyzed according to the naming, the definition and the lexical areas used in this definition, according to the time and length of the first appearance, the stages followed by the reader to recognize the character, the artwork and its relations with other characters. The features and character numbers that should be present in the characters play an important role in connecting the reader to the work. In addition to these, another important issue is the presentation methods of the characters. The narration of the author alone or the introduction of the characters with only dialogues may not satisfy the reader. The broader the author's presentation methods while introducing the character, 
the higher the probability of connecting the reader to the work (Çiçek and Aksoy, 2016, p.117).

Successful character development in literary texts can make it easier for child readers to recognize and internalize characters from different angles; It can make them turn to the reading act with more interest and desire. The reading culture of child readers who connect to the text they read through the characters can also develop more effectively. In this context, it is important to question the Turkish textbooks, which are used as a basic tool in order to teach children in the middle school the taste and habit of reading, in terms of character development ways in literary texts. Based on this importance, The aim of the study was to determine the character development methods used in literary texts in secondary school Turkish textbooks. For this purpose, the document review method was used, and the study group consisted of literary texts in Turkish textbooks prepared for 5th, 6th, 7th, and 8th grades of the secondary school and accepted by the Turkish Ministry of National Education, Head Council of Education and Morality as the education tool. The reason for the selection of literary texts is that they create a fictional world as a type of text and this fictional world allows the development of different characters.

Document analysis method was used in the research. Within the scope of the research, in the 2018-2019 academic year; The literary texts in Turkish textbooks prepared for 5 th, 6 th, 7 th and 8 th grades.

In the research, a checklist that includes character development methods was used as a data collection tool. Character development paths in this checklist are the ways of character development expressed by Lukens, and the checklist is based on the fact that the characters can be enhanced by their behavior and actions, their own speech, the interpretation of other characters, their physical characteristics, and the author's interpretation. Each of the 50 literary texts selected from Turkish textbooks to be examined was examined by the researcher using the checklist in terms of whether these character development methods were used, and the texts were analyzed using content analysis method.

As a result of the study, it was found that the most common character development method in literary texts in Turkish textbooks for all grade levels was to make characters speak, and the physical characteristics were least used in the development of characters. The speech of the characters in the 
text is very effective in determining the feelings and thoughts, inner worlds and reactions of the child readers in the face of events and situations. According to Forster (1985, p.127), one of the most powerful weapons of the writer to impress the reader is to develop the character by speaking method. Developing a character with its physical characteristics is important because it contributes to the visualization of his / her traits in the mind of the reader, to their existence as if they have gained a visible quality, and to predict some of their spiritual characteristics. According to Aktaş and Gündüz (2010), successful writers do not only give the appearance with words in their descriptions, but by adding all five senses to the act of learning, they arouse enthusiasm in the reader by giving the mood evoked by taste, color and smell.

It has been determined that the literary texts in the 5th and 6th grade Turkish textbooks of secondary school give little place to the development of the character with the interpretation of the author. However, it was determined that this method of character development was used more in 7th and 8th grades. One of the ways to develop a character that can be used in written texts is to develop the character through the interpretation of other characters. According to the findings of the research, this way of character development was found to be less in middle school Turkish textbooks at all grade levels. However, it should be emphasized that the characters are presented to child readers not only through their own speech or the introduction of the author, but also through different presentation ways by trying to convey them from different characters' languages and perspectives, and thus strengthen children's books technically (Karataş, 2014). Using different character development methods in literary texts is an approach adopted in the relevant literature (Dilidüzgün, 2007; Sever, 2008, 2013). Based on this and based on the findings obtained as a result of the research, the following suggestions can be made within the scope of the research:

The ways in which character development is carried out in literary texts in Turkish textbooks is an issue that should be emphasized. In order for children to identify with the characters in the texts they read and to internalize the characters in this way, they need to get to know them in various ways. For this reason, it should be examined whether the characters are developed not only by their speech or behavior, but also by other means in the literary texts selected for Turkish textbooks. When choosing a book, 
Turkish teachers should try to introduce books that use various character development methods to their students, and thus encourage them to read. In addition, Turkish teachers should lead their students to think and discuss what the contribution of the characters developed in different ways in the texts or books read to the text and the reader. In future studies, it may be suggested to examine character development ways in some children's books recommended for secondary school children to read and to associate them with different variables.

\section{Kaynakça / References}

Adal, O. (2006). Anlamak ve anlatmak. İstanbul: Pan Yaynncllk.

Ağın Haykır, H., Kaplan, H., Kıryar, A., Tarakc, R. ve Üstün, E. (2018). 5. SinffOrtaokul ve İmam Hatip Ortaokulu Türkçe ders kitabı (1. bs.). Ankara: Millî Eğitim Bakanliğ Yayinları.

Akgül, A., Demirer, N., Gürcan, E., Karadaş, D., Karahan, İ. ve Uysal, A (2018). 7. Sinnf Ortaokul ve İmam Hatip Ortaokulu Türkçe ders kitabı (1. bs.). Ankara: Millî Eğitim Bakanliğı Yayınları 6653.

Aksoy, B. (2009). Hikâye sanatı üzerine yazzlar. İstanbul: Pan Yayincilk.

Aktaş, Ş. ve Gündüz, O. (2010). Yazll ve sözlü anlatım. Ankara: Akçağ Yayınları.

Anderson, N. A. (2013). Elementary children's literature: infancy through age 13 (4th ed.), Boston: Pearson.

Aslan, C. (2007). Yazınsal nitelikli çocuk kitaplarınn çocuğun okuduğunu anlama ve yazil anlatım becerilerine etkisi. Eurasian Journal of Educational Research, 27, 1529.

Binyazar, A. ve Özdemir, E. (2006). Yazma öğretimilyazma sanatt, yaratıc yazma dersleri (3. bs.). İstanbul: Papirüs Yayınevi.

Ceylan, S., Duru, K., Erkek, G. ve Pastutmaz, M. (2018). 6. Sinnf Ortaokul ve Imam Hatip Ortaokulu Türkçe ders kitabı (1. bs.). İstanbul: Millî Eğitim Bakanlığ Yayınları.

Çakır, H. (2002). Öykü sanatı (1. bs.). Çizgi Kitabevi.

Çiçek, M. ve Aksoy, S. (2016). İsmet Bertan, Sevim Ak ve Görkem Yeltan'in çocuk romanlarındaki başkahramanların çözümlenmesi, SOBIDER, 3 (7), 113-131.

Dilidüzgün, S. (2004). Okuma öğretimi hedefleri bağlamında Türkçe ders kitaplarındaki çocuk edebiyatı ürünleri. Hasan Ali Yücel Eğitim Fakültesi Dergisi, 2, 43-55.

Dilidüzgün, S. (2007). Çağdaş çocuk yazım. İstanbul: Morpa Kültür Yayınları.

Doğan Güldenoğlu, B. N. (2017). Çocuk edebiyat kitaplarındaki yetişkin ve çocuk karakterlerin incelenmesi. Journal of Human Sciences, 14(4), 4768-4780.

Forster, E.M. (1985). Roman sanat. İstanbul: Adam Yayinları. 
Göktürk, A. (1997). Okuma uğraşı. İstanbul: Yapı Kredi Yayınları.

Karagöz, M. (2014). Karakter çözümlemelerinin kurgudaki yeri: "Bintepe'nin Hayaleti" Örneği. Hasan Ali Yücel Ë̆itim Fakültesi Dergisi, 11-2 (22), 139-149.

Karataş, E. (2014). Çocuk edebiyatında karakter kavramı. Muğgla Sttkı Koçman Üniversitesi Sosyal Bilimler Enstitüsü Dergisi, 33, 60-79.

Karatay H. (2011). Çocuk edebiyatı metinlerinde bulunması gereken özellikler. T. Şimşek (Ed.), Kuramdan uygulamaya çocuk edebiyatı el kitabı içinde (s. 77-123). Ankara: Grafiker Yayınları.

Karayel, Ö. F. (2018). Çetin Öner'in çocuk romanlarnnda kullanulan karakter geliştirme yöntemleri üzerine bir inceleme. Yayımlanmamış Yüksek Lisans Tezi, Ahi Evran Üniversitesi, Kirşehir.

Kardaş, C. ve Alp D. (2013). Çocuk edebiyatı ve medya. Ankara: Eğiten Kitap.

Kavcar, C. (1999). Edebiyat ve eğitim. Ankara: Engin Yayıncllk.

Kuran, A. E. ve Kuran, Z. (2000). Yazınsal okuma süreçleri (1. bs.). Ankara: SeçkinYayıncllk.

Küçükahmet, L. (2011). Eğitim programlarında ders kitabının yeri (3. bs.). L. Küçükahmet (Ed.), Konu alant ders kitabı inceleme kulavuzu (s. 13). Ankara: Nobel Yayınları.

Lukens, R.J. (1999).Critical handbook of children's literature. New York: Longman.

Mardi, H. Ö. (2006). Çocuk kitaplan resimlemede karakter yaratma. Yayımlanmamış Yüksek Lisans Tezi, Dokuz Eylül Üniversitesi, İzmir.

Mete, G., Karaaslan, M., Kaya, Y., Ozan, Ş. ve Özdemir, D. (2018). 8. Sinff Ortaokul ve İmam Hatip Ortaokulu Türkçe ders kitabı (1. bs.). İstanbul: Millî Eğitim Bakanlı̆̆ Yayinlar.

Millî Eğitim Bakanlığı (2018). Türkçe Dersi Öğretim programı (İkokul ve Ortaokul 1, 2, 3, 4, 5, 6, 7 ve 8. Sinffar). Ankara: http://mufredat.meb.gov.tr/Programlar.aspx.

Özdemir, E. (1983). Yazı ve yazznsal türler. İstanbul: Varlık Yayınları.

Özdemir, E. (2002). Yazmsal türler (5. bs.). Ankara: Bilgi Yayınevi.

Püsküllüoğlu, A. (1994). Arkadaş Türkçe sözlïk. Ankara: Arkadaş Yayınevi.

Sartre, J. P. (2005). Edebiyat nedir? (Çev. Bertan Onaran) İstanbul: Can Yayınları.

Sever, S. (2006). Çocukla yazınsal iletişim. Çocuk ve İlkgençlik Edebiyatı Kurultayı Bildirileri içinde (ss. 21-35). İstanbul: Maltepe Üniversitesi Yayın.

Sever, S. (2008). Çocuk ve edebiyat. İzmir: Tudem Yayncilk.

Sever, S. (2013). Çocuk edebiyatı ve okuma kültürü. İzmir: Tudem Yayıncllk.

Tanpınar, A. H. (1977). Edebiyat üzerine makaleler (2. bs.). İstanbul: Dergâh Yayınları.

Tuncer, H. ve Yardımcı, M. (2002). Eğitim fakülteleri için çocuk edebiyatt. Ankara: Ürün Yayınları.

Yıldırım, A. ve Şimşek, H. (2005). Sosyal bilimlerde nitel araştırma yöntemleri. (5. bs.). Ankara: Seçkin Yayıncllk. 


\section{Kaynakça Bilgisi / Citation Information}

Karakoç Öztürk, B. (2020). Yazınsal metinlerde yer alan karakter geliştirme yolları: Ortaokul Türkçe ders kitapları örneği. OPUSUluslararası Toplum Araştırmaları Dergisi, 16(32), 6362-6391. DOI: 10.26466/opus.690174 